\title{
Bonobo Conservation as a means for Local Development: an Innovative Local Initiative of Community-based Conservation in the Democratic Republic of the Congo
}

\author{
Narat V ${ }^{1 *}$, Pennec F1, Ledo-Bisson L¹, Bokika Ngawolo JC ${ }^{2}$, Dumez $\mathbf{R}^{1}$ and Krief $\mathbf{S}^{1,3}$
}

${ }^{1}$ UMR 7206 Eco-Anthropology ethnobiology (MNHN/CNRS), National Museum of Natural History, Site du Musée de l'Homme, 17 place du Trocadéro, 75016 Paris ${ }^{2}$ NGO Mbou-Mon-Tour, 2 km from Nkala Bolobo Territory, Bandundu Province, Democratic Republic of the Congo

${ }^{3}$ Project for the conservation of great apes (PCGS), 3 Titian Street, 75013, Paris

\begin{abstract}
The Democratic Republic of the Congo (DRC) ranks fifth in the world in terms of biodiversity (fauna and flora) and first for mammal diversity in Africa. There are numerous endemic species including bolobos (Pan paniscus). Bolobos are endangered, threatened mainly by deforestation, poaching and diseases, and the current population is estimated from 15,000 to 50,000 individuals. Nowadays, one national park (Salonga National Park) and six reserves exist for wild bolobo conservation, representing about $73,000 \mathrm{~km}^{2}$ of protected areas over an estimated distribution area of $565,000 \mathrm{~km}^{2}$. In the Bolobo Territory, an original local project of bolobo conservation was initiated in 2001 by the Congolese NGO Mbou-Mon-Tour (MMT). From 2008 to 2013, we studied bolobo-habitat-human interactions in this forest-savanna mosaic habitat, totalizing 12 months of survey over six periods. Besides eco-ethological studies, an ethnoecological approach was developed in order to better understand how the MMT project emerged and how it has evolved. We performed semi-structured interviews, participant observation, and informal discussions with local people. We also used grey literature associated to the region. MMT use the bolobo conservation as a means to reach local development goals, which is the opposite of what is frequent in the "community-based conservation" project managed by environmental NGOs. The location of the community forests and the rules established for regulating activities in these forests were decided by the villagers under the organization of traditional chiefs according to their knowledge on bolobo ecology and range, and the disturbance they perceived of the traditional activities in the forest. Such a process is a novel and promising approach for wildlife conservation that maintains the place of local people and traditional authorities in the decision-making process and the governance.
\end{abstract}

Keywords: Pan paniscus; Community-based conservation; Ethnoecology; Mbou-Mon-tour; Democratic Republic of the Congo

Abbreviations: BCI: Bonobo Conservation Initiative; DFGFI Diane Fossey Gorilla Fundation; DRC: Democratic Republic of the Congo; FFEM: Fond Français pour l'Environnement Mondial; ICCN: Institut Congolais pour la Conservation de la Nature; IUCN: International Union for Conservation of Nature; LCD: Local Committee of Development; LCDC: Local Committee of Development and Conservation; MMT: Mbou-Mon-Tour; NGO: Nongovernmental Organization; UGADEC: Union des Associations de Conservation de Gorilles pour le développement communautaire à l'Est de la RDC; WWF: World Wild Fund

\section{Introduction}

The Democratic Republic of the Congo (DRC) has an important role in the conservation of the environment with a large wildlife biodiversity and habitat types, ranking fifth in the world in terms of biodiversity (fauna and flora), first in Africa for mammal diversity, and with numerous endemic species [1,2], including bonobos (Pan paniscus), the last ape species known to science. Bonobos are endangered, threatened mainly by deforestation, poaching and diseases, and the current population is estimated from 15,000 to 50,000 individuals [3]. Today, one national park (Salonga National Park) and six reserves exist for bonobo conservation [3] (Figure 1), representing about $73,000 \mathrm{~km}^{2}$ of protected areas over an estimated distribution area of $565,000 \mathrm{~km}^{2}$ (13\%) [3]. Under Congolese law, the forested protected areas become "classified forest" i.e., managed by the Congolese Institute for the Conservation of Nature (ICCN), the national institution for the management of Congolese protected areas. As for other protected areas in the country and elsewhere in the world, conflicts between local people and protected area management exist about the access to the forest for human activities [4]. This situation highlights the necessity to develop other conservation models involving local people in the decision-making process and the management of protected areas to achieve truly integrated conservation. This is summed up by the broad concept of the "community-based" approach, abundantly used and commented [5-11]. Only a few cases of community-based conservation are well-documented in the DRC, whereas the process is critical for a better understanding of the evolution of conservation dynamics.

Among the great ape community-based conservation projects in the DRC, three projects have been modestly documented for bonobos (the Luo Scientific Reserve, the Kokolopori Bonobo Reserve and the Iyondji Bonobo Community Reserve) and for gorillas (the Tayna Gorilla Reserve). In the south west of the bonobo distribution area, the Bolobo Territory is the nearest area to two capital cities, Kinshasa and Brazzaville $(300 \mathrm{~km})$, to be inhabited by wild bonobos. The region is far from most national parks and from locations where bonobo

*Corresponding author: Dr. V. Narat, Museum National History Naturally, Site du Musée de l'Homme, 17 place du Trocadéro, 75016, Paris, Tel.: +331407933 59; Fax: +33 1407938 91; E-mail: vnarat@mnhn.fr

Received July 08, 2015; Accepted August 10, 2015; Published August 18, 2015

Citation: Narat V, Pennec F, Ledo-Bisson L, Bokika Ngawolo JC, Dumez R, et al. (2015) Bonobo Conservation as a means for Local Development: an Innovative Local Initiative of Community-based Conservation in the Democratic Republic of the Congo. J Primatol 4: 127. doi:10.4172/2167-6801.1000127

Copyright: (c) 2015 Narat V, et al. This is an open-access article distributed under the terms of the Creative Commons Attribution License, which permits unrestricted use, distribution, and reproduction in any medium, provided the original author and source are credited. 
Citation: Narat V, Pennec F, Ledo-Bisson L, Bokika Ngawolo JC, Dumez R, et al. (2015) Bonobo Conservation as a means for Local Development: an Innovative Local Initiative of Community-based Conservation in the Democratic Republic of the Congo. J Primatol 4: 127. doi:10.4172/21676801.1000127

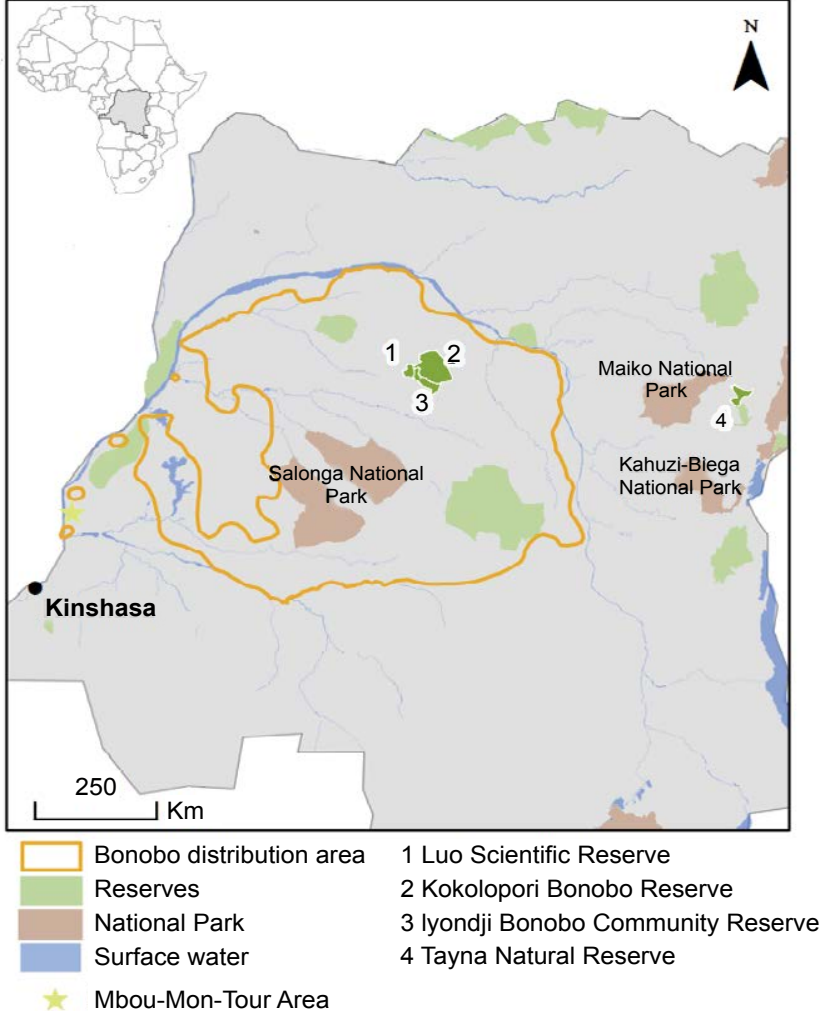

Figure 1: Location of the study area compared to the bonobo distribution area and the protected areas in the DRC.

conservation projects exist ( $500 \mathrm{~km}$ from the closest - Salonga National Park). Moreover, the habitat is composed by a forest-savanna mosaic, which is very rare in the bonobo distribution area [12-16]. Locally, the Batéké people respect a traditional eating-taboo concerning bonobos that they neither kill nor eat $[13,14,17]$ and have shared their territory with them for centuries [18]. A community-based conservation project has been in progress in this area for 14 years, led and initiated by a local Non Governmental Organization (NGO) named Mbou-Mon-Tour (MMT). Today the bonobo plays a significant role in the development of the project. Here, we describe the emergence, history and evolution of this project in order to understand the role of local people in the decision-making process and the management of the area, and to assess if this initiative is a replication of an existing model or an original process of community-based conservation in the DRC, which is interesting when reconsidering conservation blueprints.

\section{Information Sources}

\section{Great ape conservation and local people in the DRC}

We used available bibliography (scientific articles and institutional reports) to assess the context of emergence of the best known community-based conservation projects for great apes in the DRC. We extracted information related to the initiators of the project, the role of local people in the decision-making process and the governance, and the results in terms of status of the protected area. We used data regarding the four projects modestly documented for great ape conservation: Luo Scientific Reserve, Kokolopori Bonobo Reserve, Iyondji Community Bonobo Reserve and Tayna Natural Reserve.

\section{A new study case-mbou-mon-tour}

Our study area is a very particular site for bonobo studies (forestsavanna mosaic, capital city proximity, human presence) (Figures 1 and 2). Locally, the Batéké are the main ethnic group and respect a traditional eating-taboo on bonobos that they consider as a human ancestor. Several legends concern bonobo origins but the most reported is that the bonobo was first a human and had loan that he could not pay. He fled to the forest to avoid becoming a slave (ancestral custom law) and became a bonobo. Batéké people depend on the forest where they have a lot of activities, mainly slash-and-burn shifting agriculture, hunting, fishing and gathering (Table 1).
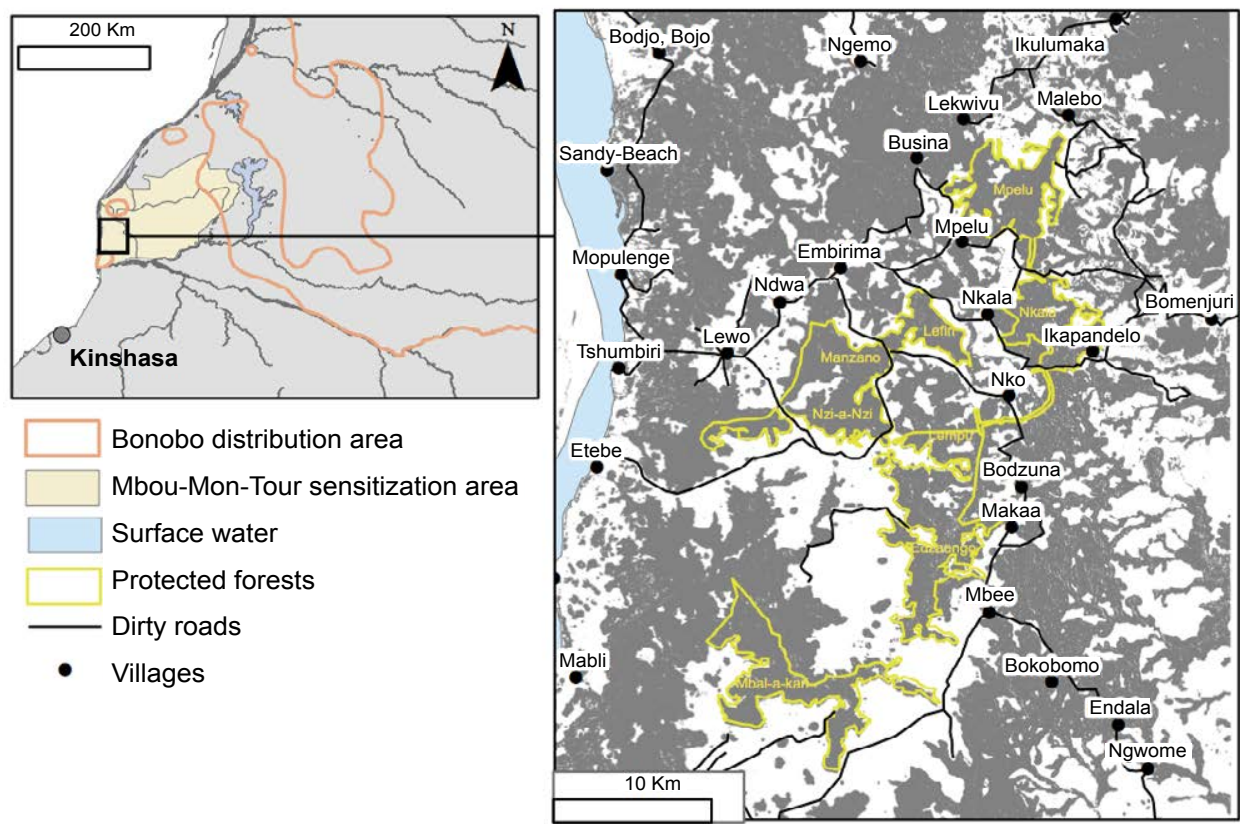

Figure 2: Approximate range of MMT for sensitization on bonobo conservation and boundaries of the protected forests determined by chiefs, LCDC and villagers. 
Citation: Narat V, Pennec F, Ledo-Bisson L, Bokika Ngawolo JC, Dumez R, et al. (2015) Bonobo Conservation as a means for Local Development: an Innovative Local Initiative of Community-based Conservation in the Democratic Republic of the Congo. J Primatol 4: 127. doi:10.4172/21676801.1000127

After a first encounter with the NGO and the local people for a pilot study in 2008 (six weeks), VN and SK started with MMT a longterm research project on bonobos in 2010 in the Manzano forest, near the Embirima village (Figure 2) [14,15]. From 2010 to 2013, five field campaigns (10 months in total) were conducted to habituate and study wild bonobos. Semi-structured interviews $(n=28)$ were conducted with local people during these periods. Three main topics composed the grid of these interviews: (1) human activities in the environment, (2) focused discussion on hunting practices and (3) focused discussion on the conservation project (definition of conservation, protected forests and consequences on the human activities). Participant observation (local daily activities, wedding, meeting for bonobo conservation...) was also conducted during the ten month field campaign. Information

\begin{tabular}{|c|c|c|c|}
\hline Human activities & $\begin{array}{c}\text { Status in } \\
2010-2012\end{array}$ & $\begin{array}{c}\text { Arguments of } \\
\text { interlocutors about } \\
\text { human activities status in } \\
\text { protected forests (2010- } \\
\text { 2012) }\end{array}$ & $\begin{array}{c}\text { Status in } 2013 \\
\text { (in the "procès } \\
\text { verbaux") }\end{array}$ \\
\hline \multirow{2}{*}{$\begin{array}{l}\text { Slash-and- } \\
\text { burn shifting } \\
\text { agriculture }\end{array}$} & No & $\begin{array}{c}\text { Total protection } \\
\text { Disturb bonobos Risk of } \\
\text { crop raiding }\end{array}$ & \multirow[t]{2}{*}{ Forbidden } \\
\hline & Yes & $\begin{array}{l}\text { If small and at the forest } \\
\text { edge }\end{array}$ & \\
\hline Hunting - rifle & No & $\begin{array}{c}\text { Total protection } \\
\text { Disturb bonobos (noise) }\end{array}$ & Forbidden \\
\hline $\begin{array}{l}\text { Hunting - snares } \\
\text { (large wire) }\end{array}$ & No & $\begin{array}{l}\text { Total protection } \\
\text { Mutilations }\end{array}$ & Forbidden \\
\hline \multirow{2}{*}{$\begin{array}{l}\text { Hunting - snares } \\
\text { (little wire and } \\
\text { nylon) }\end{array}$} & No & $\begin{array}{l}\text { Total protection } \\
\text { Mutilations }\end{array}$ & \multirow[t]{2}{*}{ Forbidden } \\
\hline & Yes & No mutilations & \\
\hline \multirow[t]{2}{*}{ Hunting - net } & No & $\begin{array}{l}\text { Total protection } \\
\text { Disturb bonobos }\end{array}$ & \multirow[t]{2}{*}{ Forbidden } \\
\hline & Yes & & \\
\hline Fishing - poison & No & $\begin{array}{l}\text { Total protection } \\
\text { Water pollution }\end{array}$ & Forbidden \\
\hline \multirow[t]{2}{*}{ Fishing - bailout } & No & $\begin{array}{c}\text { Total protection } \\
\text { Disturb bonobos (noise) }\end{array}$ & \multirow[t]{2}{*}{ Authorized } \\
\hline & Yes & & \\
\hline \multirow{2}{*}{ Fishing - hooks } & No & Total protection & \multirow{2}{*}{ Authorized } \\
\hline & Yes & Not disturb bonobos & \\
\hline \multirow{2}{*}{$\begin{array}{l}\text { Fishing - fish } \\
\text { traps }\end{array}$} & No & $\begin{array}{c}\text { Total protection } \\
\text { Disturb bonobos (noise) }\end{array}$ & \multirow[t]{2}{*}{ Authorized } \\
\hline & Yes & Not disturb bonobos & \\
\hline \multirow{2}{*}{$\begin{array}{c}\text { Mushrooms } \\
\text { and Caterpillars } \\
\text { gathering }\end{array}$} & No & Total protection & \multirow[b]{2}{*}{ Authorized } \\
\hline & Yes & $\begin{array}{l}\text { Not disturb bonobos and } \\
\text { local needs }\end{array}$ & \\
\hline \multirow{2}{*}{$\begin{array}{l}\text { Gathering - } \\
\text { Marantaceae } \\
\text { leaves }\end{array}$} & No & $\begin{array}{c}\text { Total protection } \\
\text { Bonobo alimentation } \\
\text { Availability in other forests }\end{array}$ & \multirow[t]{2}{*}{ No status } \\
\hline & Yes & $\begin{array}{l}\text { Not disturb bonobos } \\
\text { Local needs }\end{array}$ & \\
\hline $\begin{array}{l}\text { Gathering - } \\
\text { Raphia }\end{array}$ & Yes & $\begin{array}{c}\text { No bonobo in forests with } \\
\text { Raphia }\end{array}$ & No status \\
\hline \multirow{2}{*}{$\begin{array}{l}\text { Gathering - } \\
\text { lianas }\end{array}$} & No & $\begin{array}{c}\text { Total protection } \\
\text { Availability in other forests }\end{array}$ & \multirow{2}{*}{ No status } \\
\hline & Yes & $\begin{array}{l}\text { Not disturb bonobos } \\
\text { Local needs }\end{array}$ & \\
\hline $\begin{array}{c}\text { Gathering - } \\
\text { medicinal plants }\end{array}$ & 1 & 1 & No status \\
\hline $\begin{array}{l}\text { Wood fuel / Wood } \\
\text { construction }\end{array}$ & No & $\begin{array}{c}\text { Total protection } \\
\text { Bonobo alimentation and } \\
\text { habitat }\end{array}$ & No status \\
\hline
\end{tabular}

Table 1: Status of human activities in protected forests before the signature of the minutes ("procès verbal") and status in the minutes. "No status" refers to activities observed on the field but not mentioned in the minutes. from informal discussions with the local people encountered (traditional chiefs, local authorities, hunters, cattle breeders, NGO workers, field assistants, traders...) and grey literature (MMT annual reports, field reports from partners and students, legal documentation on the registration of the NGO) were collected to have a better understanding of the conservation project's emergence and evolution. Overall, discussions with more than 60 people were conducted throughout the ten month field campaign and ten interlocutors were regular (discussions occurred in several field campaigns). Information was mainly gathered around the villages of Nkala, Embirima, Nko and Bodzuna (Figure 2).

A qualitative analysis of interlocutor speeches was made to understand the wide spectrum of knowledge and perception of the conservation project. The purpose was not to provide a quantitative analysis of the different opinions but to understand the history and the evolution of the project and which actors were included in the decision-making process and the management. Moreover, based on grey literature, the history of the community-based conservation project was analyzed to have a better understanding of the project's evolution.

Great ape conservation and local people in the DRC: who initiated the community-based conservation projects?

The scientists-Luo scientific reserve: In 1990, researchers working at Wamba (the first study site for wild bonobos set up in 1974) and the Congolese government decided to create the Luo Scientific Reserve (Figure 1). In order to maintain the traditional co-existence between bonobos and local people, the Bongando people, who respect an eating-taboo on this species [19], they chose to create a reserve instead of a national park in which human activities are prohibited. Some human activities were authorized in the reserve and numerous local development projects were achieved but the decision-making process did not include local people. Conflicts between local people and protected areas have emerged since the reserve's creation, and are more and more frequent due to a change in lifestyle [20]. This is the first documented example of a will to integrate local people and great ape conservation in the DRC.

\section{Local NGOs supported by international NGOs: Tayna natural reserve and Kokolopori Bonobo reserve}

In the East of the country, the Tayna Natural Reserve (Figure 1), which was created in 2006 mainly for gorilla conservation (Gorilla beringei graueri), is considered as a national model of communitybased conservation [21-23]. The project started with a local NGO (The Tayna Gorilla Reserve) created in 1998 by an agent from the ICCN. Since 2000, the Diane Fossey Gorilla Foundation International (DFGFI) has been supporting the project in order to create the reserve and strengthen local capacities. This project has shown the key role played by international NGOs in the creation process and the development of the Reserve. This protected area was based on the Man and Biosphere blueprint, i.e. with a gradient of protection levels (core zone, buffer zone, transition zone) [23]. Local people federated in local NGOs manage the protected area supported by the DFGFI and under the supervision of the ICCN [21-23]. Conservationists suggested the creation of this kind of project [21]. This example is characteristic of the community-based conservation project with mainly conservation goals and where local development is a means to reach these goals [2325]. The "Tayna model" was replicated at several locations in the region for gorilla conservation with a network managed by the "Union des Associations de Conservation Gorillas for Community Development 
Citation: Narat V, Pennec F, Ledo-Bisson L, Bokika Ngawolo JC, Dumez R, et al. (2015) Bonobo Conservation as a means for Local Development: an Innovative Local Initiative of Community-based Conservation in the Democratic Republic of the Congo. J Primatol 4: 127. doi:10.4172/21676801.1000127

in Eastern DRC (UGADEC meaning "Union of Associations of Gorilla Conservation for the Community Development in the East of the DRC") and inspired two bonobo conservation projects (Kokolopori Bonobo Reserve and Sankuru Nature Reserve) [21]. Little information is available to understand the mechanisms at the origin of these bonobo conservation projects and the role of local people in the decision-making and management of these protected areas. In the case of Kokolopori, a local NGO ("Vie Sauvage" meaning "Wild Life") was at the beginning of the project in 2000, and in 2001 the American NGO Bonobo Conservation Initiative (BCI) started to support this project. $\mathrm{BCI}$ has developed several projects on the same model.

In the cases of both Tayna and Kokolopori, the projects began in a region where the great apes' presence was already known and admitted by scientists and conservationists. Moreover, there was a goal to create a network of protected areas (linked with the Luo Scientific Reserve for Kokolopori and between two National Parks for Tayna). The main difference between these two projects is probably that in Kokolopori, $\mathrm{BCI}$ have adopted an Information Exchange approach to understand local people's perception in order to involve them at the beginning in the conservation project [26].

\section{Local communities supported by scientists and international ngos: Iyondji community Bonobo reserve}

Adjacent to the Luo Scientific Reserve and the Kokolopori Bonobo Reserve, the Iyondji Community Bonobo Reserve was created in 2012. In 2007, local communities asked to Japanese researchers from Wamba (Wamba Committee for Bonobo Research) and to an international NGO, the African Wildlife Foundation, to help them to create the reserve [27]. Although this reserve is claimed to be from and for local people, this is a classified forest, i.e., the area is managed by the ICCN. Unfortunately, there is little information available to better analyze the decision-making process and the governance of this protected area. It seems that the long-term goal is to create a network of protected areas for bonobo conservation [28]. However, there is a lack of collaboration between international conservation NGOs in this region and conflicts due to the desire to be the stakeholder leading the bonobo conservation [26].

Based on these few examples of community-based conservation projects for great apes in the DRC, the roles of local people seems poorly considered in the decision-making process and the governance. Although for Luo, scientists thought of the well-being of local people, they did not involve them in the creation and development of the project. For Tayna, Kokolopori and Iyondji, scientists and/or NGOs from other countries very soon supported these initiatives. Little information is available on the evolution of the projects. Moreover, these initiatives appeared in regions where the conservation was already implanted and the presence of great apes was known by scientists and conservationists facilitating the process. In all cases, (1) the area was gazetted as "reserve", meaning that forests became under the management of the ICCN and (2) the ultimate goal was the great ape conservation while the local development was a means to obtain a network of protected areas. We can see a kind of chronology with first the Luo Scientific Reserve initiated by scientists without local people, then the Tayna model with a local NGO supported by an international one and the Iyondji case where both scientists and an international NGO were involved at the beginning of the project. In this landscape of community-based conservation projects for great apes in the DRC, we will describe hereafter the history and evolution of the MbouMon-Tour initiative to better understand the evolution of great ape conservation dynamics in the DRC.

\section{Origins and development of the original case of Mbou-Mon- Tour: Bonobo conservation for local development}

An urgent need to secure food resources for the future: In 1997, villagers and people with an academic background native of Nkala village created the Congolese NGO Mbou-Mon-Tour (MMT), registered as a local development NGO, following the ascertained decrease of local natural faunal forest resources (game and fish) described by most local people. JCB, the president of the NGO, member of the chief clan of Nkala, had been a judge for more than 25 years in the DRC's capital city, Kinshasa, and kept strong bonds with his village. In 1997, the NGO first created a pilot farm to promote cattle breeding and have a place to test alternative subsistence activities (out of the forest). Training was provided to local people for these new activities.

Protection of the Bonobo: In 2001, the Nkala village decided to protect its forest $\left(16.6 \mathrm{~km}^{2}\right)$ for bonobo conservation and they created the first local protected forest of the area. At the beginning, the protection of the forest had two main goals: (1) stop the erosion of the traditional eating-taboo which had been going on for several years and the subsequent poaching of bonobos and (2) create an eco-tourism site as a local development means. However, several actors of national and international conservation did not believe this local NGO when it announced the presence of bonobos at a distance of only $300 \mathrm{~km}$ from Kinshasa in a forest-savanna mosaic. The MMT staff was composed of neither scientists nor conservationists and had no way to take pictures of unhabituated wild bonobos to prove bonobo presence. Thanks to the perseverance of MMT, JCB talked to scientists from WWF during the Great Ape Survival Project meeting in Kinshasa, in 2005. Then, WWF scientists came on the field, confirmed the presence of this ape species and created the Malebo station, $16 \mathrm{~km}$ from the MMT farm about two years later [29]. The first census provides one of the most important known density estimation for bonobos at the landscape scale ( $2.2 \mathrm{ind} /$ $\mathrm{km}^{2}$ ) with an estimated population of about 2,000 individuals despite the forest-savanna mosaic habitat which is not typical of this species $[13,29]$. More recently, a study performed at a local scale gave a more precise estimation and currently reported a density of about 0.5 ind./ $\mathrm{km}^{2}$ in the Nkala and Mpelu forests [16].

Expansion of the project: Influenced by the evolution of the Nkala project, five other villages created local protected forests $\left(175 \mathrm{~km}^{2}\right.$ in total) on their traditional territory (Figure 2) supported logistically by MMT (Mpelu-2005, Mbee-2005, Bodzuna-2005, Embirima-2006, Makaa-2010) and two protected forests (Embirima and Mbee) were extended in 2010 for monkey conservation (Cercopithecus ascanius whitesidei, C. wolfi, C. neglectus, Lophocebus aterrimus, Colobus angolensis angolensis, and Piliocolobus tholloni) following recommendations of a new partner (The Conservatoire for Primate Protection, a French NGO linked to the French zoo "La Vallée des Singes"). In each village, local trackers worked voluntarily to start the creation of a trail network in protected forests for bonobo/monkey monitoring. In Nkala, Mpelu, and Mbee, even if MMT is at the origin of the project, WWF has paid trackers and managed these sites since 2006. In the other sites, trackers worked voluntarily until 2012 and were then paid by MMT supported by recent partnerships with western zoos and environmental NGOs. Bonobo habituation is in process in Nkala and Mpelu sites (led by WWF) and at Embirima (led by VN and MMT) [15]. The sites of Mbee, Bodzuna and Makaa are only for the monitoring of bonobos in order to protect them but to avoid having more than three bonobo communities under a habituation process, as recommended by the IUCN [30]. Table 2 summarizes characteristics of the different sites. There is no governmental eco-guard in these 
Citation: Narat V, Pennec F, Ledo-Bisson L, Bokika Ngawolo JC, Dumez R, et al. (2015) Bonobo Conservation as a means for Local Development: an Innovative Local Initiative of Community-based Conservation in the Democratic Republic of the Congo. J Primatol 4: 127. doi:10.4172/21676801.1000127

protected forests with no official status of protected area. Most of the population is involved in this project and the information flows between villages allow a kind of control to prevent bonobo poaching. Besides non-human primate conservation, MMT also lead awareness campaigns, local development projects, and is involved in scientific studies.

Raising awareness about Bonobo conservation: Since the beginning of the Bonobo conservation in the first village (2001), MMT has worked with traditional chiefs and opinion leaders (in schools, churches, local authorities) to strengthen the eating-taboo and to remind people that custom, national and international laws forbid killing bonobos. They have led several education campaigns, one lasting six months with the "Great apes and their habitat" education kit [31]. More than 6,000 pupils and adults were made aware about the importance of great ape and forest conservation. Since the beginning, the awareness is an important part of the work of MMT and is conducted on five territories (Bolobo, Muschie, Yumbi, Inongo and $\mathrm{Kutu}$ ) on an area over $25,000 \mathrm{~km}^{2}$ (Figure 2). Consequently, the erosion of the eating-taboo has been reduced by MMT campaigns since 2001. Two villages (Nkala in 2008 and Mopulenge in 2010) created folkloric bands and used traditional music and theater to broadcast messages on bonobo conservation, local custom and local conservation projects. These initiatives of local people are also important for a good integration of awareness in the long-term.

Local development projects: Development projects are based on local people's need, they concern mainly alternative subsistence activities and infrastructure rehabilitation. Since 2012, MMT and its partners have been developing more and more agriculture projects (diversification of crops) and small ruminant breeding in order to decrease dependence on the forest for subsistence. Moreover, recently, programs to increase household income are in process. Rehabilitation of a dispensary, roads and bridge to facilitate links with local markets were also carried out. With the different partners, they are also involved in the payment for ecosystem service projects, mainly a nursery garden of a local Uapaca species, naturally present at the edge of the forest, for promoting the reforestation process and developing agroforestry. At the beginning of the project, 12 people worked voluntarily for bonobo tracking and received two cows from the MMT cattle. Today, about 70 people work thanks to MMT and its partners and the monthly salary is between 70 and 150 USD, i.e., an important income in this region. The villages involved in the conservation are the main beneficiaries of local development projects but other villages benefit from these projects, mainly for infrastructure rehabilitation.

Scientific projects in the area: Scientific projects, mainly on bonobos, forest ecology and relationships between local people and bonobos, have been performed since 2006 in the Nkala and Mpelu sites by the WWF and since 2010 at the Embirima site by VN, SK and MMT. In the latter, five members of MMT were trained (since 2010) for scientific research (transect creation, transect run in order to collect human and non human primates evidence and for phenology survey). In 2013, a first local training was also conducted for the collection of all the fauna evidence due to the collaboration with The Conservatoire for Primate Protection.

Relationships between WWF and MMT: WWF tried to appropriate this project, as claimed in the first communication on a new population of bonobos discovered by WWF [29], but MMT has succeeded in maintaining local interest and the central role of the local population. For example, whereas WWF wanted to create the Local Committee of Development (LCD), a classic way to involve local people in participatory management [32], MMT obtained that these committees were also for the conservation (Local Committee of Development and Conservation, LCDC). Indeed, MMT wanted to highlight the role of local people in the management of protected forests and not only in local development projects. MMT refuses to become a service provider for an international NGO who claim that they involved local people. Several other difficulties occurred between WWF and local people, like the absence of a participatory approach at the beginning of the mapping (2010) at the north of the area, where WWF did not involve traditional chiefs to determine the limits of an unofficial protected area. In their partnership document, which was only signed in 2012 due to some disagreements, whereas WWF engagements are mainly on empowerment of MMT and strengthening local capacities, MMT engagements are mainly on the mediation between local people and WWF in order to decrease conflicts and

\begin{tabular}{|c|c|c|c|c|c|c|c|}
\hline Site Name & $\begin{array}{c}\text { Village involved } \\
\text { (year of } \\
\text { beginning) }\end{array}$ & Target species & Management & Funders/Partners & $\begin{array}{l}\text { Number of } \\
\text { trackers } \\
(2015)\end{array}$ & $\begin{array}{l}\text { Mapping and } \\
\text { minutes }\end{array}$ & Main goal \\
\hline Nkala & Nkala (2001) & Pan paniscus & WWF & MMT, WWF & 9 & Yes & Habituation \\
\hline Mpelu & Mpelu (2005) & Pan paniscus & WWF & MMT, WWF & 9 & Yes & Habituation \\
\hline $\begin{array}{l}\text { Manzano } \\
\text { Nzi-a-Nzi }\end{array}$ & $\begin{array}{l}\text { Embirima (2006), } \\
\text { Bodzuna (2006) }\end{array}$ & Pan paniscus & MMT & $\begin{array}{c}\text { MMT, Conservatoire pour la protection } \\
\text { des primates, Save Our Species, } \\
\text { Bonobo ECO }\end{array}$ & $\begin{array}{l}10+2 \\
\text { research field } \\
\text { assistants }\end{array}$ & Yes & Habituation \\
\hline Lempu & $\begin{array}{l}\text { Bodzuna (2005), } \\
\text { Makaa (2010) }\end{array}$ & Pan paniscus & MMT & $\begin{array}{l}\text { MMT, Conservatoire pour la protection } \\
\text { des primates, Save Our Species, } \\
\text { Fondation Nature et Découverte }\end{array}$ & 7 & Yes & Monitoring \\
\hline Lefiri & Embirima (2010) & $\begin{array}{l}\text { Lophocebus atterimus } \\
\text { Cercopithecus Ascanius, C. } \\
\text { neglectus, C. wolfii }\end{array}$ & MMT & $\begin{array}{l}\text { MMT, Conservatoire pour la protection } \\
\text { des Primates, Save Our Species }\end{array}$ & 7 & Yes & Monitoring \\
\hline Edzaengo & Mbee (2005) & Pan paniscus & WWF & $\begin{array}{l}\text { MMT, WWF, Conservatoire pour la } \\
\text { protection des primates, Save Our } \\
\text { Species }\end{array}$ & 4 & Yes & Monitoring \\
\hline Mbal-a-kari & Mbee (2010) & $\begin{array}{c}\text { Lophocebus atterimus, } \\
\text { Piliocolobus sp., Colobus } \\
\text { angolensis, Cercopithecus } \\
\text { Ascanius, C. neglectus, C. wolfii }\end{array}$ & MMT & $\begin{array}{l}\text { MMT, WWF, Conservatoire pour la } \\
\text { protection des primates, Save Our } \\
\text { Species }\end{array}$ & 6 & Yes & Monitoring \\
\hline Mbominzoli & Mongama (2013) & Pan paniscus & MMT & MMT, Awely & 4 & In process & Monitoring \\
\hline
\end{tabular}

WWF: World Wide Fund; MMT: Mbou-Mon-Tour

Table 2: Comparison of the management and objective of the protected forests in the Mbou-Mon-Tour area. 
Citation: Narat V, Pennec F, Ledo-Bisson L, Bokika Ngawolo JC, Dumez R, et al. (2015) Bonobo Conservation as a means for Local Development: an Innovative Local Initiative of Community-based Conservation in the Democratic Republic of the Congo. J Primatol 4: 127. doi:10.4172/21676801.1000127

allowing WWF to work in favorable conditions in the area. This reveals that WWF needs MMT to work in this area and to be accepted by local people. Here, there is a lack of data to better analyze the interactions between the stakeholders involved in this project, but it is essential to perform this kind of study in this area.

Compared to the existing community-based conservation projects on great apes in the DRC, local people are at the initiative of the project (contrary to the case of Luo) and MMT was not supported at the beginning by a foreign NGO (contrary to Tayna, Kokolopori and Iyondji). In brief, the originalities of the emergence context of this project are: (1) a local NGO of development used bonobo conservation as a means to improve local people's way of life, (2) the region was not considered to be inhabited by bonobos and so it was long and difficult to acquire credibility facing conservationists and (3) they sought to have different partners and they avoided to be blocked by one international NGO, working to maintain their independence, their role in the decision-making process and the governance of the area. We have seen that MMT seemed to bring new elements to better understand the local people's involvement in great ape conservation in the DRC. Besides this, MMT also participates in an evolution on the protected area statuses. We will describe hereafter what a protected forest is in this area and how they want to avoid a classic conservation blueprint.

\section{The protected forests: a means to avoid a classic blueprint of "classified forest"}

Location of protected forests in MMT: a balance between bonobo abundance and human activities: According to semi-structured interviews and informal discussion, the choice of the location of protected forests depends on bonobo presence and on human use (local knowledge). In most cases, villagers have chosen forests where bonobos were abundant and where human activities (mainly slash-andburn shifting agriculture) were not a priority (in general far from the village). Until 2013 boundaries were not fixed and people had different considerations about the location and delimitation of protected forests. For example, in the case of Embirima, according to some interlocutors, protected forests were only where bonobo trackers worked but for others it included a larger part of the forest, based on forest vernacular names. In 2011, for the chief of Embirima, who is traditionally the land manager, the protected forests were initially larger than the area where trackers worked, but some villagers outside Embirima did not respect these boundaries. Local needs and the lack of project supporters did not permit to stabilize the original protected area boundaries. The same pattern was found at Bodzuna, where a central area was consensual for everyone (the area where trackers worked) but the total protected area had not the same boundaries for all interlocutors.

In order to fix boundaries, MMT, supported by the Fond Français pour l'Environnement Mondial (IUCN/FFEM), achieved the participatory mapping of local protected forests according to the traditional authorities, the LCDC and villagers. Traditional chiefs, notables, LCDC representatives and other villagers discussed and approved the boundaries obtained by participatory mapping in each village. Finally, protected forests are larger than those where bonobo trackers work. Existing agricultural areas at the edge of these protected forests were maintained as crop lands and not included in the protected areas. In the case of the Embirima, limits correspond to those indicated by the chief in 2011 . Overall, it covers a total of $175 \mathrm{~km}^{2}$ with small corridors linking all the protected forests between the different sites, corresponding to four bonobo forest blocks and two monkey forest blocks (Lophocebus aterrimus, Colobus angolensis, Piliocolobus tholloni,
Cercopithecus neglectus, C. ascanius whitesidei, and C. wolfi) (Figures 2 and 3).

Rules in protected forests guided by eco-ethological knowledge on bonobos: Rules in protected forests are linked to authorized human activities and those which are forbidden. Speech about human activities in protected forest can be divided into two categories: the partial protection speech and the total protection speech.

In the case of partial protection, three main considerations are taken into account to explain protection rules: avoiding bonobo disturbance, local needs and availability of resources in unprotected forests. Thus it mobilizes traditional ecological knowledge (bonobo ecology, resource availability) and it is constrained by the "need to eat today" reality $[33,34]$. All interlocutors with a partial protection speech defined the protected forests as an area where hunting with rifles and large wire is forbidden. Other activities have a variable status. For example, the hunting with small wire (unselected wires mainly for small mammals and rodents) is authorized for some people in local community forests because "it cannot hurt Bonobos" and for others it is forbidden because "Bonobos play a lot on the ground and can play with the wire and trap their fingers". In this area, the consequences of trapping do not seem very large. Indeed, in the Manzano forest, $\mathrm{VN}$ observed two bonobos with mutilations probably due to wire: one adult male with four missing fingers on the right hand from the unit-group under habituation (out of 23 individuals), and an adult male with a missing hand in another unit group, which is a low impact compared to Sebitoli chimpanzees in the Kibale National Park, Uganda [35]. Non-hunting activities also have a variable status. For example, the gathering of Marantaceae leaves (daily use for a culinary purpose) is permitted for some interlocutors because this activity does not disturb bonobos and forbidden for others since these herbaceous plants are important food for bonobos.

In the case of what is called "total protection", the people providing the information were WWF workers or were participants of WWF meetings. According to two WWF workers, only the bonobo trackers can enter protected forests. Their speech was not based on bonobo

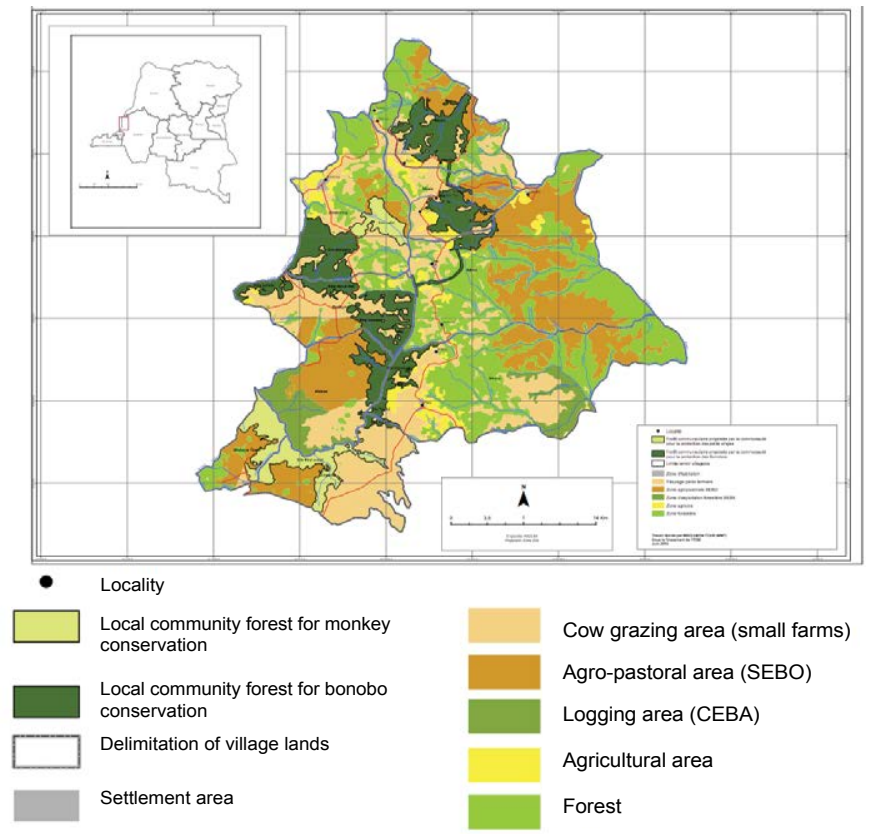

Figure 3: Results of the participatory mapping managed by MMT (๑ MMT). 
Citation: Narat V, Pennec F, Ledo-Bisson L, Bokika Ngawolo JC, Dumez R, et al. (2015) Bonobo Conservation as a means for Local Development: an Innovative Local Initiative of Community-based Conservation in the Democratic Republic of the Congo. J Primatol 4: 127. doi:10.4172/21676801.1000127

conservation but on nature conservation in general (all the forest components are protected). One interlocutor (in Bodzuna village) explained that humans could not enter protected forests because it was kept for protection and forests are important to "preserve air quality". Moreover, game reproduction will result in an exit of game from protected areas to unprotected areas where it will then be hunted. Here we find the messages broadcasted by the international NGO conservation.

At the same time as participatory mapping (2013), chiefs, LCDC and other representatives of villages signed minutes with MMT (locally called "procès verbal") of the meeting to formalize the "consent of the inhabitants [...] for the creation of their community forest". These documents (one in each village) correspond to four pages describing local involvement in bonobo and forest conservation for several years, project history (MMT and its partners) and defining rules inside local community forests.

In addition to the two activities (hunting with rifles and large wire) that were considered forbidden by everyone, other activities were added (all hunting methods, fishing by water poisoning, and slash-andburn agriculture). Mushrooms, caterpillar and fishing (hooks, bailout fishing) are authorized. Table 1 summarizes the statuses of human activities according to interlocutors (2010-2012), their arguments and the statuses of human activities in the minutes. Some activities observed in the forest and described by local people are not mentioned in the minutes ("no status"). These activities were defined by the information collected during interviews and participant observations.

Thus, villagers and traditional chiefs chose the rules inside the protected forests, but these rules will probably evolve according to the evolution of the projects.

Protected forests have variable statuses: local authorities: The traditional authorities have shown their commitment in the guarantee of protected forests in 2012 when a logging company started operating in the area with an artisanal logging permit. In the villages involved in the conservation program organized by MMT and its partners, the traditional chiefs refused to let the company extract timber (mainly Millettia laurentii) in the local community forest areas. This choice epitomizes the reality of the involvement of the custom authorities in conservation. Even if WWF was already in the area, the MMT network was mobilized, including traditional chiefs, to prevent logging in the protected forests.

Concerning local police authorities, the evolution of the perception of local police officers is informative. In 2010 they considered one of us, $\mathrm{VN}$, who was conducting a research survey, as a person who came to steal bonobos to take and sell them in Europe or to look for diamonds in the forest. At this time they did not believe our research goal on wild bonobos in collaboration with traditional chiefs and MMT. Three years later, police officers have changed their discourses and they promised that they would arrest any villager who entered protected forest and insisted on the importance of bonobo protection. According to four different interlocutors, three women from the Ndwa village, close to the Manzano forest (Figure 2), were arrested by police officers in 2013 because they gathered Marantaceae leaves for culinary purposes in a protected forest. It was explained they were disturbing the bonobos and the trackers' work. They had to pay a symbolic penalty to the police authorities. This event shows the evolution of the consideration of the project by local authorities. Even if some human activities have no status in the minutes, main disturbance activities are forbidden and the principal goal about human presence for other activities to avoid disturbing the bonobos and trackers' work. As for timber extraction, MMT had a main role because these women entered Manzano forest, a protected forest where WWF is not present. Policemen were made aware by the increasing presence of visitors and partners but also by the campaign (formal or informal) performed by MMT.

Traditional authorities have been involved in bonobo conservation since the beginning of the project (indeed for a very long time, through the traditional eating-taboo), and with the awareness campaigns of the NGO, even local authorities are now aware of the bonobo protected forests.

National status: To avoid the exclusion of the initiators of community-based conservation in this area, MMT wants to use article 22 of the Congolese forestry code permitting the creation of "community forests". This article was first designed for the artisanal logging authorizing local exploitation managed by local people but MMT wants to use this way to create community forests for conservation. Since 2002, this article's legislation has not been implemented, but recently (August $2^{\text {nd }}, 2014$ ) this legislation was implemented by the Congolese Prime Minister. A delegation of the Ministry of Environment, Conservation, Nature and Tourism travelled to the MMT area in July 2014 to assess the local involvement in conservation, and the procedure is pending, because there is a need to clarify the law before creating these local community forests. Several authors had advocated the importance of this article for improving the possibilities of forest community management in the DRC [36].

International institutions: As we have seen before, since 2005, MMT had several international partners. In 2012, the support of IUCN, via the Fonds Français pour l'Environnement Mondial (FFEM), was an important step to confirm the credibility of the local NGO opposite national and international institutions. They supported the lobbying for the formalization of local community forests through article 22 of the forestry code and also supported MMT in its actions for alternative activities and awareness campaigns. In 2014 MMT was recognized as an innovative conservation project and in November 2014, its president was invited to the Congress Park in Sydney (Australia). This international credibility was also observed in the cases of Kokolopori and Tayna.

In summary, for several years, the boundaries and rules inside protected forests were not fixed but villagers claimed protected areas. Since 2013, although protected forests areas were clearly determined by villages, rules inside are not entirely clear. This dynamic highlights the slow process in the area, with a comprehensive approach, i.e. rules are not imposed on local people but they are chosen step by step according to their knowledge, their needs and the influence of the different partners. In comparison with previous examples, it seems that the decision for boundaries is quite similar, fixed by participatory mapping with the agreement of local people. However, the choice for the type of protection is different. Contrary to the other examples of communitybased conservation projects, where the protected area is finally a reserve defined as community-based conservation but under the supervision of the ICCN, and human activities are forbidden (hunting and all activities degrading the habitat), villagers have chosen the rules in their protected forests according to their knowledge. Although it could be a problem because of a lack of regulation, villagers are at the origin of these rules, which could facilitate their compliance with them. Table 3 summarizes the characteristics of the different community-based conservation project for great apes in the DRC. 
Citation: Narat V, Pennec F, Ledo-Bisson L, Bokika Ngawolo JC, Dumez R, et al. (2015) Bonobo Conservation as a means for Local Development: an Innovative Local Initiative of Community-based Conservation in the Democratic Republic of the Congo. J Primatol 4: 127. doi:10.4172/21676801.1000127

Page 8 of 11

\begin{tabular}{|c|c|c|c|c|c|c|c|c|c|c|c|}
\hline & $\begin{array}{l}\text { Starting } \\
\text { year } \\
\text { of the } \\
\text { project }\end{array}$ & Initiators & $\begin{array}{c}\text { First } \\
\text { Support } \\
\text { (year) }\end{array}$ & $\begin{array}{l}\text { Proximity } \\
\text { to } \\
\text { existing } \\
\text { protected } \\
\text { areas }\end{array}$ & $\begin{array}{c}\text { Conservation } \\
\text { status* } \\
\text { (year of } \\
\text { creation) }\end{array}$ & $\begin{array}{c}\text { Forest } \\
\text { classification } \\
\text { (Forestry } \\
\text { Code) })^{* *}\end{array}$ & $\begin{array}{c}\text { Design of } \\
\text { conservation } \\
\text { area }\end{array}$ & $\begin{array}{l}\text { Local } \\
\text { people } \\
\text { in the } \\
\text { decision- } \\
\text { making } \\
\text { process }\end{array}$ & Management* & $\begin{array}{c}\text { Main } \\
\text { conservation } \\
\text { target }\end{array}$ & References \\
\hline $\begin{array}{l}\text { Tayna } \\
\text { Natural } \\
\text { reserve }\end{array}$ & 1998 & $\begin{array}{l}\text { Local NGO of } \\
\text { conservation }\end{array}$ & $\begin{array}{l}\text { DFGFI } \\
(2000)\end{array}$ & \begin{tabular}{|} 
Virunga, \\
Kahuzi- \\
Biega and \\
Maiko \\
National \\
Parks
\end{tabular} & $\begin{array}{c}\text { Natural } \\
\text { Reserve } \\
(2006)\end{array}$ & $\begin{array}{l}\text { Classified } \\
\text { Forest }\end{array}$ & $\begin{array}{c}\text { Full protection } \\
\text { zone }\left(900 \mathrm{~km}^{2}\right) \\
\text { Buffer zone; } \\
\text { Development } \\
\text { zone }\end{array}$ & Yes & $\begin{array}{c}\text { Co- } \\
\text { Management } \\
\text { (under ICCN } \\
\text { supervision) }\end{array}$ & $\begin{array}{c}\text { Gorillas } \\
\text { Chimpanzees }\end{array}$ & 23 \\
\hline $\begin{array}{l}\text { Luo } \\
\text { Scientific } \\
\text { Reserve }\end{array}$ & 1990 & Scientists & 1 & I & $\begin{array}{c}\text { Scientific } \\
\text { Reserve } \\
(1990)\end{array}$ & $\begin{array}{l}\text { Classified } \\
\text { Forest }\end{array}$ & $\begin{array}{c}\text { Partial } \\
\text { protection } \\
\text { (some human } \\
\text { activities are } \\
\text { authorized), } \\
481 \mathrm{~km}^{2}\end{array}$ & No & $\begin{array}{l}\text { Top-down } \\
\text { outside } \\
\text { management }\end{array}$ & Bonobos & 23 \\
\hline $\begin{array}{c}\text { Kokolopori } \\
\text { Bonobo } \\
\text { Reserve }\end{array}$ & 2000 & $\begin{array}{l}\text { Local NGO of } \\
\text { conservation }\end{array}$ & $\begin{array}{c}\mathrm{BCl} \\
(2001)\end{array}$ & Luo & $\begin{array}{c}\text { Natural } \\
\text { Reserve } \\
(2009)\end{array}$ & $\begin{array}{c}\text { Classified } \\
\text { Forest }\end{array}$ & $\begin{array}{c}\text { Blueprint of } \\
\text { Tayna Natural } \\
\text { Reserve, } 4,785 \\
\text { km² }^{2}\end{array}$ & Yes & $\begin{array}{c}\text { Co- } \\
\text { Management } \\
\text { (under ICCN } \\
\text { supervision) }\end{array}$ & Bonobos & 23,26 \\
\hline $\begin{array}{c}\text { lyondji } \\
\text { Community } \\
\text { Bonobo } \\
\text { Reserve }\end{array}$ & 2007 & $\begin{array}{l}\text { Local NGO of } \\
\text { conservation }\end{array}$ & $\begin{array}{c}\text { AWF and } \\
\text { Scientists } \\
(2007)\end{array}$ & $\begin{array}{l}\text { Luo and } \\
\text { Kokolopori }\end{array}$ & $\begin{array}{c}\text { Community } \\
\text { Reserve } \\
(2012)\end{array}$ & $\begin{array}{l}\text { Classified } \\
\text { Forest }\end{array}$ & $1,100 \mathrm{~km}^{2}$ & Yes & $\begin{array}{c}\text { Co- } \\
\text { Management } \\
\text { (under ICCN } \\
\text { supervision) }\end{array}$ & Bonobos & 27 \\
\hline $\begin{array}{c}\text { Mbou-Mon- } \\
\text { Tour }\end{array}$ & 2001 & $\begin{array}{l}\text { Local NGO of } \\
\text { development }\end{array}$ & $\begin{array}{l}\text { WWF } \\
(2006)\end{array}$ & I & In process & $\begin{array}{l}\text { Local } \\
\text { community } \\
\text { forests } \\
\text { (in process) }\end{array}$ & $\begin{array}{l}\text { Some human } \\
\text { activities are } \\
\text { authorized, } \\
\text { network of } \\
\text { protected forest } \\
\text { patches, } \\
175 \mathrm{~km}^{2}\end{array}$ & Yes & In process & $\begin{array}{l}\text { Bonobos and } \\
\text { monkeys }\end{array}$ & This study \\
\hline
\end{tabular}

* according to Horwich and Lyon, 2007 [8].

Table 3: History comparisons of community-based conservation projects for great apes in DRC.

\section{A new step in the self-determination of local people in the} DRC?

The self-determination of local people is a critical point in the community-based conservation debate. Indeed, as for the association of conservation and development goal problems, some communitybased conservation projects are not based on local self-determination but are promoted by national or international institutions (through local development means). This study case could be a new step in the self-determination of local people for conservation in the DRC. Indeed, with national parks, there was no consultation of local people, and in reserves, there was an important influence of international NGOs or scientific projects with little involvement of local people in the decision-making process $[21,22]$. In the case of MMT, there were neither scientists nor conservationists at the beginning of the project. Obviously, all partners (fund providers, scientists, collaborators) have had an influence in the progress of the process but MMT has kept its specificity and its independence. The president of MMT has identified bonobos as a flagship species for both local people (customary laws) and for the international community. Bonobo conservation and research, including census and information on their range, were used as a motor of development to reach development goals but also to upgrade local customs. Since the beginning of the project, there have been very few conflicts between MMT and local people because they founded MMT themselves and they are very well settled in the area.

The design of the protected area is also an evidence of a new step in self-determination. Indeed, local people themselves have fixed boundaries and rules inside protected forests. In this habitat conformation, and human presence in savannas, they have created what is the beginning of a protected area network (with some human activities allowed), linked by corridors. It seems to be a good alternative in this forest-savanna mosaic habitat with an overlap between human and bonobo habitat uses. Finally, they want to maintain their selfdetermination by the creation of community forest, based on article 22. In case of the procedure's success, local people will really be recognized as responsible in the management and the governance of the local community forests, which would be an important step in the recognition of their self-determination. Obviously, they will always work in collaboration with the Congolese government and the competent institutions (especially ICCN), but with this status, the protected lands will not be gazetted as "classified forests". For now, there is no protected forest really managed by local people in the DRC [37] whereas decentralized management is one of the goals of the DRC's constitution (2006). This system of management could permit to return to the traditional system that existed before colonization and it seems to be an interesting alternative way to manage the fauna and flora biodiversity of the DRC [38].

\section{Limits and perspectives of the MMT project}

Mixing conservation and development: Several authors have highlighted a problem in the community-based conservation projects: they are under the management of international or national institutions, local development is not a major goal but is just a means to reach conservation goals and there is a gap between theory and realities as regards the local involvement in management and the decision-making process [23-25, 39]. For Berkes [40], there is no sense for conservation without land use for local people (except in the case of sacred sites or species taboos) because they are excluded from their lands and their responsibility for land management.

On the other hand, one of the main criticisms of community- 
Citation: Narat V, Pennec F, Ledo-Bisson L, Bokika Ngawolo JC, Dumez R, et al. (2015) Bonobo Conservation as a means for Local Development: an Innovative Local Initiative of Community-based Conservation in the Democratic Republic of the Congo. J Primatol 4: 127. doi:10.4172/21676801.1000127

based conservation projects from some conservationist practitioners is the inefficiency of this kind of project to reach conservation goals. Conservation and local development goals cannot be reached at the same time because it leads to the dissatisfaction of local people and no significant results in conservation [10]. Local people are only concerned by development goals and are not really involved in conservation goals, which leads to a loss of local biodiversity [41]. In the case of MMT, the starting point was the local ascertainment of the decrease of natural resources and a will for local development. Bonobo conservation was identified as a means of local development for two reasons: local custom laws protect the species and internationally bonobo are a flagship and an endangered species, which was identified as a potential motor for local development. The main difficulty at this local scale is governance and the capacity of coordination of actions between each village because there is no eco-guard and the project is based on mutual trust. However, there is an important investment in conservation. Indeed, local trackers entered the forest voluntarily for several years before being given a job thanks to several partners. Local people are also involved to avoid bonobo poaching and habitat degradation as it was done during the illegal timber exploitation in this region.

Moreover, in general, no quantitative evaluation of the effect of the conservation (for instance an increase in wildlife populations) is available in these community-based conservation projects $[8,42]$. The Tayna Reserve is a good example of the opposite. Indeed, one of the founders was an ICCN agent and, in 2001 they made transects run to collect evidence of mammals. In 2005 and 2006 they ran the same transects and showed a significant increase in the rate of evidence of gorillas, chimpanzees and elephants [38]. In the case of MMT, this process takes more time because the local people were not trained and all the process evolved in a collaborative and progressive way. One of the main weaknesses is the lack of quantitative evaluation of the project according to biodiversity conservation. This needs to be improved, and recently (2014), a scientific committee was created gathering MMT members and partners with scientific, conservation and development skills, to strengthen local capacity and develop the project. The objective is to have a protocol at each site allowing a better monitoring of bonobo and monkey presence and human activities in the local community forest. Thus, year by year, quantitative data will be available to assess the conservation effort. From that, awareness will be improved according to each site's specificities. Before considering an increase in biodiversity to evaluate the MMT conservation project, we have to focus first on the stabilization of the bonobo population and local development projects to keep the strong link existing between local people and this project.

\section{Stability and fragility of the MMT project}

The sustainability of this innovative initiative of bonobo conservation depends on the involvement of local people. Changes in local perception and practices about conservation can lead to the failure of this project. On the other hand, even when local people are not included in conservation projects, their acceptance or not of the project has important consequences on its success. In the Luo Scientific Reserve, local people have changed their way of life because of human migration and mixing between ethnic groups. They don't respect the protected areas and there are some conflicts between local people and conservationists/scientists [20]. Nowadays, we cannot predict the evolution of protected areas in the MMT area but several parameters give us information to assess this evolution. MMT has been running awareness campaigns for 14 years, and whereas at the beginning some villagers did not believe the importance of bonobo conservation for their local development, they are now aware that bonobo conservation can lead to a better well-being for the local people. Several local development projects are underway and local people are now convinced by the success of bonobo conservation to help them to reach development goals. There is a strong pride of local people to have succeeded in the first step of this project, they now have credibility and legitimacy in the world of ape conservation. The feeling of pride is often felt by villagers because in this region visitors (partners, students, researchers) from different countries come only in this area to see bonobos and the work of MMT whereas there are no visitor elsewhere in this Territory. In 2013, during the $26^{\text {th }}$ congress of the Francophone Society of Primatology, 36 participants travelled also in the area (in three trips), which was an important step for local communities as an experiment of eco-tourism. MMT members are also invited to present their project in international congresses (MMT president and coordinators) or workshops (local trackers of several sites and field coordinators). Moreover, a national TV channel (Environews, RTNC2) produced documentary on this initiative. In addition to the awareness raised by MMT and its partners, local initiatives use traditional music and theater to spread information on bonobo conservation and local traditional customs on bonobo status.

The small scale of the project, with a progressive evolution by trial and error is a positive point for its effectiveness and sustainable success [8]. Moreover, the internal target motivators for conservation (the bonobo as a traditional eating-taboo and the bonobo as a motor of development) are also a positive point for the long-term durability of the project [11]. However, there is a lack of coordination and a need to strengthen local capacities. In 2015, a workshop was organized with the IUCN and the NGO Well-Grounded in order to improve it. As in the Kokolopori project, there is collaboration between local people, scientists, and conservation and development NGOs. However, in the case of MMT, it seems that the local NGO has kept its independency from bigger NGOs. Dialogue between these actors is necessary in order to adapt strategies according to context evolution [43]. In the near future, eco-tourism will probably begin. The site is probably the best shaped for ecotourism due to its proximity to Kinshasa, and the relative ease of access. It is an important project, one of the first goals of the creation of local community forests, and all partners collaborate to avoid disasters like disease transmission from humans to habituated bonobos or the destabilization of the area because of differences in the redistribution of benefits. The scientific committee was also created for this goal. Concerning eco-tourism, the redistribution of potential benefits is not still formalized, it needs the involvement of the national authorities, which is in process at the same time as the formalization of the local community forests. Thus, it will be critical in the future to better study relationships between the different stakeholders and to monitor the conditions for the first eco-tourists and the redistribution of benefits. Indeed, eco-tourism can create important benefits but in many places the sharing poses problems and causes frustration for local people [44].

\section{A potential network of local community forests as an alternative to classic network of protected areas?}

More and more villages are contacting MMT to be a part of the project and there is a possibility to create a network of local community protected areas. This would be a very important step for bonobo conservation in this region, where the human presence is important with a fragmented habitat (forest-savanna mosaic). Kawamoto et al. [45] have shown that bonobo populations from the west of the distribution area were relatively isolated from the central population. 
Citation: Narat V, Pennec F, Ledo-Bisson L, Bokika Ngawolo JC, Dumez R, et al. (2015) Bonobo Conservation as a means for Local Development: an Innovative Local Initiative of Community-based Conservation in the Democratic Republic of the Congo. J Primatol 4: 127. doi:10.4172/21676801.1000127

Raising awareness over large areas could permit to decrease bonobo poaching in the region and broaden the local community forests network. The most important step for the future is the legalization of protected areas as community forests with the implementation of article 22 of the forestry code. If the procedure succeeds, the process should be facilitated for other villages. Further studies on the consequences of this project are in process to understand how the MMT project modifies local perceptions and practices [17], but also to deeply analyze the relationships between stakeholders.

\section{Conclusion}

This study case is an innovative approach for primate conservation in the DRC, mixing conservation and local development goals. Local people are at the initiative of the project and the development of partnerships with several institutions including scientific and conservation organizations has permitted to increase local knowledge and capacities in management and governance. They have reached a high level in self-determination and are deeply committed to this project, for both goals: conservation and development. This initiative has also been taken as an example in other villages and the result could be a network of community conservation forests. This study case could bring a new blueprint between development and conservation goals in the DRC, based on the involvement of local people themselves and the credibility acquired over time face to local, national and international institutions. For now, the long-term success of the project is not assured, as for all conservation projects, but this is a real hope for bonobo conservation in this region of the distribution area. Finally, it would be necessary to have more descriptions of the context of emergence and management of the community-based conservation projects in order to gather the initiatives and improve the involvement of local people in the management of these areas.

\section{Acknowledgements}

We thank the Ministère de l'Environnement, Conservation de la Nature et Tourisme for research permission, the Mbou-Mon-Tour NGO and traditional chiefs for authorization to conduct this work. Acknowledgements for funding are due to the Action Transversale du Muséum "Relations Sociétés-Nature dans le long terme" and the UMR7206 Eco-anthropology and Ethnobiology. We also thank all members of Mbou-Mon-Tour for their support and contribution to bonobo conservation. Thank you to lan Nicholson for the improvement of written English.

\section{References}

1. de Wasseige C, de Marcken P, Bayol N, Hiol Hiol F, Mayaux P, et al. (2012) Les forêts du bassin du Congo - Etat des Forêts 2010. Office des publications de l'Union Européenne, Luxembourg.

2. Debroux L, Hart T, Kaimowitz D, Karsenty A, Topa G (2007) Forests in post-conflict Democratic Republic of Congo: analysis of a priority agenda. A joint report by teams of the World Bank, Center for International Forestry Research (CIFOR), Centre International de Recherche Agronomique pour le Développement (CIRAD), African Wildlife Foundation (AWF), Conseil National des ONG de Développement du Congo (CNONGD), Conservation International (CI), Groupe de Travail Forêts (GTF), Ligue Nationale des Pygmées du Congo (LINAPYCO), Netherlands Development Organisation (SNV), Réseau des Partenaires pour l'Environnement au Congo (REPEC), Wildlife Conservation Society (WCS), Woods Hole Research Center (WHRC), World Agroforestry Centre (ICRAF) and World Wide Fund for Nature (WWF). 82p.

3. IUCN, ICCN (2012) Bonobo (Pan paniscus): conservation strategy 2012-2022. IUCN/ICCN, Gland $69 \mathrm{p}$.

4. IUCN/PACO (2010) Parcs et Réserves de la République Démocratique du Congo : évaluation de l'efficacité de gestion des aires protégées. UICN/PACO, Ouagadougou. $148 \mathrm{p}$.

5. Western D, Wright (1994) Natural Connections: Perspectives in CommunityBased Conservation., D.C: Island Press, Washington.

6. Agrawal A, Gibson CC (1999) Enchantment and disenchantment: The role of community in Natural Resource Conservation. World Development 27: 629649

7. Berkes F (2004) Rethinking Community-based conservation. Conservation Biology 18: 621-630

8. Horwich RH, Lyon J (2007) Community conservation: practitioners' answer to critics. Oryx 41: 376-385

9. Kaimowitz D, Sheil D (2007) conserving what and for whom? Why conservation should help meet basic human needs in the tropics. Biotropica 39: 567-574.

10. Marie CN, Sibelet N, Dulcire M, Rafalimaro M, Danthu P, et al. (2009) Taking into account local practices and indigenous knowledge in an emergency conservation context in Madagascar. Biodiversity and Conservation 18: 27592777.

11. Souto T, Deichmann JL, Núñez C, Alonso A (2014) Classifying conservation targets based on the origin of motivation: implications over the success of community-based conservation projects. Biodiversity and Conservation 23: 1331-1337.

12. Thompson JAM, Boesch C, Hohmann G, Marchant LF (2002) Bonobos of the Lukuru Wildlife Research Project. Behavioural diversity in chimpanzees and bonobos. Cambridge University Press, Cambridge: 61-70.

13. Inogwabini BI, Bewa M, Longwango M, Abokome M, Vuvu M, et al. (2008) The Bonobos of the Lake Tumba - Lake Maindombe Hinterland: threats and opportunities for population conservation., The Bonobos: Behavoior, Ecology and Conservation. Springer, New York: 273-290.

14. Narat V, Cibot M, Bokika Ngawolo JC, Dumez R, Krief S (2012) Etude préliminaire de l'influence des disponibilités alimentaires et des activités humaines sur l'utilisation spatiale de l'habitat par les chimpanzés et les bonobos. Revue de primatologie 4 [En ligne].

15. Narat $V$, Pennec F, Simmen B, Ngawolo JCB, Krief S (2015) Bonobo habituation in a forest-savanna mosaic habitat: influence of ape species, habitat type, and sociocultural context. Primates.

16. Serckx A, Huynen MC, Bastin JF, Hambuckers A, Beudels-Jamar RC, et al. (2014) Nest Grouping Patterns of Bonobos (Pan paniscus) in Relation to Fruit Availability in a Forest-Savannah Mosaic. PLoS ONE 9: e93742.

17. Narat V, Pennec F, Krief S, Ngawolo JCB, Dumez R (2015) Conservation communautaire et changement de statuts du bonobo dans le Territoire de Bolobo: Animal juridique, économique et écologique. Revue d'ethnoécologie 7 [Online].

18. Inogwabini BI, Nzala AB, Bokika JC (2013) People and bonobos in the southern Lake Tumba Landscape, Democratic Republic of Congo. American Journal of Human Ecology 2: 44-53.

19. Lingomo B, Kimura D (2009) Taboo of eating bonobos among the Bongando people in the Wamba region, Democratic Republic of Congo. African Study Monographs 30: 209-225.

20. Idani G, Mwanza N, Ihobe H, Hashimoto C, Tashiro Y, et al. (2008) Changes in the status of bonobos, their habitat, and the situation of humans at Wamba in the Luo Scientific Reserve, Democrativ Republic of Congo. The Bonobos: Behavoior, Ecology and Conservation. Springer, New York: 291-302

21. Mehlman P (2010) La Réserve Naturelle communautaire de Tayna en République Démocratique du Congo: une approche de conservation et de gestion des ressources par la base. Central African Regional Program for the Environment, International Union for Conservation of Nature. Landscape-scale conservation in the Congo Basin: lessons learned from the Central African Regional Program for the Environment (CARPE). IUCN, Gland: 67-83.

22. Mukulumanya M, Vermeulen C, Kalinda A, Mate JP (2014) La gestion communautaire des ressources naturelles à l'Est de la RD Congo: expérience de l'UGADEC. Parcs \& Réserves 68: 11-15.

23. Vikanza PK (2011) Aires protégées, espaces disputés et développement au Nord-est de la RD Congo. Dissertation de thèse. Université Catholique de Louvain. 343 p.

24. Balint PJ (2006) Improving Community-based conservation near protected areas: the importance of development variables. Environ Manage 38: 137-148.

25. Berkes F (2007) Community-based conservation in a globalized world Proceedings of the National Academy of Sciences 104: 15188-15193.

26. Bechard D (2015) Des Bonobos et des Hommes, voyage au cœur du Congo. Ecosociété, Montréal, $462 \mathrm{p}$. 
Citation: Narat V, Pennec F, Ledo-Bisson L, Bokika Ngawolo JC, Dumez R, et al. (2015) Bonobo Conservation as a means for Local Development: an Innovative Local Initiative of Community-based Conservation in the Democratic Republic of the Congo. J Primatol 4: 127. doi:10.4172/21676801.1000127

27. Sakamaki T, Kasalevo P, Bokamba MB, Bongoli L (2012) lyondji community bonobo reserve: a recently established reserve in the Democratic Republic of Congo. Pan Africa News 19: 16-19.

28. Dupain J, Fowler A, Kasalevo P, Sakamaki T, Lingomo B, et al. (2013) The process of creation of a new protected area in the Democratic Republic of Congo: The xase of the lyondji Community Bonobo Reserve. Pan Africa News 20: $10-13$.

29. Inogwabini B-I, Matungila B, Mbende L, Abokome M, Tshimanga T (2007) Great apes in the Lake Tumba landscape, Democratic Republic of Congo: newly described populations. Oryx 41: 532-538.

30. Macfie EJ, Williamson EA, IUCN/SSC Primate Specialist Group (2010) Lignes directrices pour de meilleures pratiques en matière de tourisme de vision des grands singes. Gland, Suisse: Groupe de spécialistes des primates de la CSE/ UICN

31. Krief S, Nambogwe H, Mankoto S, Krief JM (2009) Malles pédagogiques itinérantes «les grands singes et leur habitat»: parcours et premières évaluations de l'impact du projet en Ouganda et au Gabon. Revue de primatologie 1 [En ligne].

32. Raghunathan N, Ansay F, Nsenga L (2013) Gestion participative des ressources naturelles dans les Réserves de Biosphère. L'expérience du WWF dans les réserves de Luki, Yangambi (RDC) ei Dimonika (République du Congo). Guide technique WWF-Belgique. $27 \mathrm{p}$

33. Wilkie DS, Carpenter JF, Zhang Q (2001) The under-financing of protected areas in the Congo Basin: so many parks and so little willingness-to-pay. Biodiversity \& Conservation 10: 691-709.

34. Justice C, Wilkie D, Zhang Q, Brunner J, Donoghue C (2001) Central African forests, carbon and climate change. Climate Research 17: 229-246.

35. Krief S, Cibot M, Bortolamiol S, Seguya A, Krief JM, et al. (2014) Wild Chimpanzees on the Edge: Nocturnal Activities in Croplands. PLoS ONE 9: e109925.
36. Yanggen D, Angu K, Tchamou N, Agnagna M (2010) Central African Regional Program for the Environment, International Union for Conservation of Nature. Landscape-scale conservation in the Congo Basin: lessons learned from the Central African Regional Program for the Environment (CARPE). IUCN, Gland $262 \mathrm{p}$

37. Sunderlin WD, Hatcher J, Liddle M, Rights (2008) Resources Initiative From exclusion to ownership?: challenges and opportunities in advancing forest tenure reform. Rights and Resources Initiative, Washington pp. 54.

38. Roe D, Nelson F, Sandbrook C (2009) Gestion communautaire des ressources naturelles en Afrique: impacts, experiences et orientations futures. Série Ressources Naturelles $n^{\circ} 18$. Institut International pour l'Environnement et le Développement, Londres. pp. 222.

39. Binot A, Hanon L, Joiris DV, Dulieu D (2009) The challenge of participatory natural resource management with mobile herders at the scale of a SubSaharan African protected area. Biodiversity and Conservation 18: 2645-2662.

40. Berkes F (2008) Sacred ecology. Routledge, New York. 313 p.

41. Sanderson SE, Redford KH (2003) Contested relationships between biodiversity conservation and poverty alleviation. Oryx 37: 389-390.

42. Agrawal A, Redford K (2006) Poverty, development, and biodiversity conservation: Shooting in the dark? Ann Arbor Ml 48109: 647-5948.

43. Tewksbury J, Wagner G (2014) The role of civil society in recalibrating conservation science incentives: civil society and conservation incentives. Conservation Biology 1-3.

44. Adams WM, Infield M (2003) Who is on the gorilla's payroll? Claims on tourist revenue from a Ugandan National Park. World Development 31: 177-190.

45. Kawamoto Y, Takemoto H, Higuchi S, Sakamaki T, Hart JA, et al. (2013) Genetic structure of wild bonobo populations: diversity of mitochondrial DNA and geographical distribution. PLoS ONE 8: e59660.
Citation: Narat V, Pennec F, Ledo-Bisson L, Bokika Ngawolo JC, Dumez R, et al. (2015) Bonobo Conservation as a means for Local Development: an Innovative Local Initiative of Community-based Conservation in the Democratic Republic of the Congo. J Primatol 4: 127. doi:10.4172/2167-6801.1000127
OMICS International: Publication Benefits \& Features

Unique features:

Increased global visibility of articles through worldwide distribution and indexing

Showcasing recent research output in a timely and updated manner

Special issues on the current trends of scientific research

Special features:

700 Open Access Journals

50,000 Editorial team

Rapid review process

Quality and quick editorial, review and publication processing

Indexing at PubMed (partial), Scopus, EBSCO, Index Copernicus, Google Scholar etc.

Sharing Option: Social Networking Enabled

- Authors, Reviewers and Editors rewarded with online Scientific Credits

Better discount for your subsequent articles

Submit your manuscript at: http://www.omicsonline.org/submission 